\title{
The Analysis of Language Skills Proportion in English Textbook Grade XI Published by Kemendikbud 2014
}

\author{
Indah Damayanti, Dian Eka Chandra Wardhana, Mei Hardiah, Yuni Wulandari \\ Faculty of Teachers Training and Education, University of Bengkulu, Jl. W.R. Supratman, Kandang Limun, Bengkulu, \\ Indonesia \\ Corresponding e-mail: indah_078@yahoo.co.id
}

\begin{abstract}
The main part of teaching and learning process is good materials and activity for students which are represented by a textbook. Evaluation on a textbook is needed in order to evaluate the content to the need of teaching and learning process and the goal of the curriculum. This research aims to evaluate English textbook grade XI published by Kemendikbud 2014 on the proportion of language skills (including grammar). The method used was descriptive quantitative. The object of the research was English textbook grade XI published by Kemendikbud (first and second semester). There are five chapters for the first semester and six chapters for the second semester. The total chapter was eleven. The instrument was evaluation checklist adapted from Four Strand's theory by Nation and Macalister (2010). The result showed that the proportion of language skills represented by English textbook Grade XI published by Kemendikbud 2014 was not balanced for all components of language skills. Writing, Grammar, and Speaking were represented in balanced proportion while Reading and Listening were not balanced. These two portions were represented very poorly, $7 \%$ for Reading and $1 \%$ for Listening. These findings need to be re-evaluated in order to make the textbook is able to use properly and suit to the goal of English learning as stated in the Curriculum.
\end{abstract}

Keywords: textbook, Kemendikbud, evaluation, proportion, language skills

\section{INTRODUCTION}

The Ministry of Education and Culture (2016) states that the goal of English subject syllabus for Senior High School and vocational high school is to develop students' potentials in order to have communicative competence in interpersonal texts, transactional, and functional, using various texts in English for oral and written. Concerning to the above goal the English class should elaborate the students' communicative competence for both oral and written. In reality, the students are not able to communicate in English sufficiently. The condition of Senior High School students, in reality, is not sufficient due to the lack of facilities in facilitating students' participation in all English skills (Listening, Speaking, Reading, and Writing). Some common obstacles in English learning rely on the availability of laboratory at schools, lack of English exposure in class, and the imbalance of four English skills in English learning at class. In addition to the non-conducive class factors, learning English at the high school level especially in Bengkulu city also experienced obstacles in terms of English teachers that perform their functions at the stage of running the routine of teachers' activities only, we can say that there is almost not any aspects of innovation and creativity in the learning activities at class (Damayanti, et al 2014).

In line with the four language skills that have not been implemented proportionally in learning process, there is an assumption in society that reading and writing skill have big proportion rather than the other skills (listening and speaking skill), for example in National Examination especially in Senior High School, the students take more time 
answering their exam on reading texts and as well as writing. It can be seen from the content of subject of National Examination (UN), the dominant questions are reading because there are a lot of texts such as narrative, descriptive, recount, and procedure text, while others skill has less portion.

The main part of teaching and learning process is a good material or activity for students. One of the basic things in teaching material is textbook. According to Brown (2000), "textbooks help teachers to prepare the lesson." Moreover, Setiabudi (2010) implies that textbook is course book used by teacher and students to facilitate the teachinglearning process that in line with the curriculum suggested. The textbook is one of guidance for the teacher to help them in delivering the material in class. It contains instruction, material or activity for the students to improve the student's skills.

Good materials and activity for students represented by a textbook are the main media in the learning process. An evaluation of textbook is considered as important to some of the educational judgments. Evaluation on a textbook is needed in order to evaluate the content to the need of teaching and learning process and the goal of the curriculum. The proportion of language skills is also a consideration to evaluate of an English textbook. Wibisono (2013) state that evaluation will enable teachers to determine whether the language learning plan fit the learners need and interest or not. This judgment will determine the quality of the textbook. This study focuses on English textbook evaluation emphasizing the proportion of language skills and grammar. This research aims to evaluate English textbook grade XI published by Kemendikbud 2014 on the proportion of language skills (including grammar).

\section{METHODS}

This research was a descriptive quantitative method focusing in evaluating English textbook on the proportion of language skills and grammar through the activities in English textbook grade XI published by Kemendikbud 2014. The object of this research was English textbook for grade XI (Senior High School) published by Kemendikbud 2014 (1st and 2nd semester). There are five chapters in the first semester and six chapters in the second semester of this English textbook. The total of a chapter in those two books is eleven.

The instrument that used by the researcher in this research was an evaluation checklist. Evaluation checklist is a list of activity and skills that is going to look at when observing the English textbook. This list prepared based on chapters and activities in English Textbook grade XI published by Kemendikbud 2014. To determine what activity belongs to a certain skill, some criteria by Nation (2007) and Nation \& Macalister (2010) were used. Those criteria will be categorized into evaluation checklist. The researcher put checklist mark $(\sqrt{ })$ in the columns of the checklist if the activities in textbook fulfilled the criteria. Each of checklist mark $(\sqrt{ })$ in the language skills and grammar column was scored one (1) for each and zero (0) for none.

\section{RESULTS AND DISCUSSION}

\subsection{Result}

3.1.1 The proportion of language skills in English textbook grade XI published by Kemendikbud 2014.

The general result of this research is shown in the following figure.

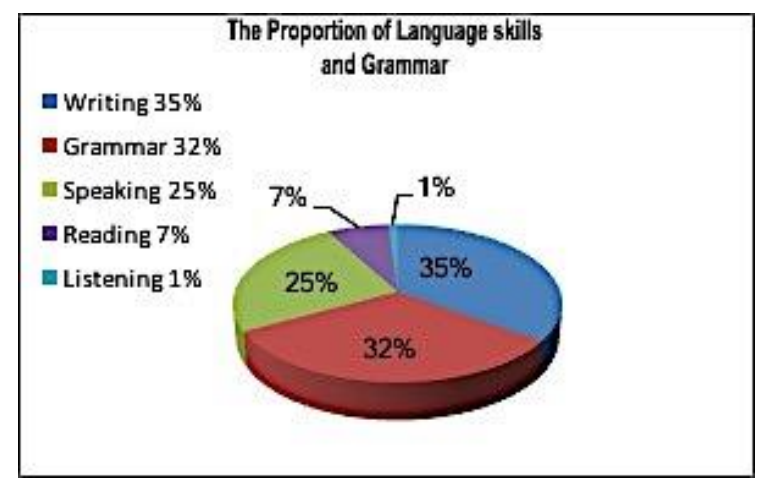

From figure 1, we can see that writing skill has the highest proportion (35\%), grammar (32\%), speaking (25\%), reading (7\%), and the lowest proportion is listening of $(1 \%)$.

\subsubsection{Proportion of Language Skills in English Textbook Grade XI Published by Kemendikbud 2014 for Each Chapter}

The Proportion of Language Skills and Grammar in chapter 1

In chapter 1, there were 18 activities. Each activity examines students' ability in language skill. However, speaking and writing were placed dominantly in elaborating students' language skill. They achieved $34 \%$ respectively of the total activities. Grammar was the next big proportion $(25 \%)$, then reading $7 \%$, and the last is listening $0 \%$. In chapter 1 , it was found that there were not any activities required students' listening ability otherwise the teacher creates and develops the instruction of the activities. Some activities were categorized into more than one skills, for example, 
the first activity contains speaking and writing Most of the activities require students to work on writing and speaking than reading and listening skill.

\section{The Proportion of Language Skills and Grammar in chapter 2}

In chapter 2, there were 17 activities. Speaking skill and grammar took the portion bigger than other skills (33\%) for each of total activities. Then, it is followed by the similar proportion of writing and grammar (30\%), and again listening was not represented explicitly in the instruction of activities while other skills were instructed explicitly in the activities. In this chapter, students were required to focus more on speaking and grammar.

\section{The Proportion of Language Skills and Grammar in chapter 3}

In chapter 3, there were 14 activities. Each activity examines students' ability in language skill. However, speaking was placed as the highest proportion in elaborating students' language skill $(35 \%)$. Then, it is followed by the similar proportion of writing and grammar $(30 \%)$, then, reading was the fourth proportion of only $5 \%$. In chapter 1 , we can say again that listening was not elaborated explicitly through the activities in this chapter; otherwise, the teacher creates and develops the instruction of the activities. Some activities were categorized into more than one skill, for example, some activities contain reading and speaking. Most of the activities require students to work on speaking, writing, and grammar.

\section{The Proportion of Language Skills and Grammar in} chapter 4

There were 12 activities in chapter 4 which show a similar proportion of writing and grammar $(35 \%)$. The others skills percentage of this book are speaking $25 \%$, reading $5 \%$, and listening skill $0 \%$ or there is no listening activity in this chapter still.

\section{The Proportion of Language Skills and Grammar in chapter 5}

Chapter 5 contain 13 activities and shows the same result as chapter 4 . The result was $35 \%$ writing, $35 \%$ grammar, $25 \%$ speaking, $5 \%$ reading and $0 \%$ listening. There is not any different to chapter 4 .

\section{The Proportion of Language Skills and Grammar in chapter 6}

Chapter 6 consist of 13 activities. The activity that mostly appears in this textbook was writing activity. Writing skill considered as the extremely important for students to understand the questions and material that they learned. From previous chapters until chapter 6 , the highest proportion of language skills still was grasped by writing. It was evidenced by the percentage from the evaluation checklist, Writing 38\%, grammar 33\%, speaking $24 \%$, reading $5 \%$, and $0 \%$ for listening skill.

The Proportion of Language Skills and Grammar in chapter 7

Chapter 7 which consist of 12 activities show no significant differences among the proportion of language skills and grammar activity. In this chapter, the writing skill as the highest portion and grammar is the second highest proportion than the other skills. Writing 39\%, grammar 33\%, speaking 22\%, reading $6 \%$, and listening skill $0 \%$ or it can be said again that there were not any listening activities in this chapter.

\section{The Proportion of Language Skills and Grammar in} chapter 8

The number of activities in this chapter was 15 and shows that grammar activity as the highest proportion of $45 \%$ above writing skill. Writing skill decreased into $32 \%$. Next, speaking skill was $14 \%$, reading increase to $9 \%$ and listening skill as the same of previous chapters, only for $0 \%$.

\section{The Proportion of Language Skills and Grammar in chapter 9}

There were 12 activities belong to chapter 9 which shows that writing skill as the highest proportion of $44 \%$ above the grammar and other language skills. In this chapter focus more on writing skill, followed by grammar $33 \%$, speaking $17 \%$ and reading was the fourth proportion only $6 \%$ and listening.

\section{The Proportion of Language Skills and Grammar in chapter 10}

Chapter 10 displays the biggest number of activities (23) and shows that there are some proportions of listening skill because of this chapter about "Meaning through Music". This chapter presented some of songs and poetry. Songs seem able to make students want to listen in order to know the tone, after knowing the tone, they know about the feeling and meaning through the song. This song also is integrated with other skills such as reading, writing and speaking. For example, the students are asked to listen to a song that given by the teacher based on the book that they use. Next, read the lyrics, then the students are asked to know what the song is about and put it into their writing. After writing it down, students can express their opinions about the song. This chapter mix all the language skills, the proportion of writing skill still as the highest proportion of $32 \%$, speaking and reading was $23 \%$, grammar $16 \%$, and $6 \%$ of listening. 
The Proportion of Language Skills and Grammar in chapter 11

In chapter 11, it was only 11 activities. The last chapter of the English textbook grade XI published by Kemendikbud 2014 still shows that writing skill as the highest proportion of $37 \%$, followed by grammar $32 \%$, speaking $26 \%$, reading $5 \%$, and listening $0 \%$.

\subsection{Discussion}

In Indonesia, especially in Bengkulu province, some schools apply 2013 curriculum. Therefore, the researchers analyzed the English textbook grade XI published by kemendikbud 2014 because it is in line with the implementation of the latest curriculum. The assumption is that listening and speaking are smaller than reading and writing proven by National Examination especially for Senior High School examining students more on reading the text and answering the question. People can see from the content of subject of National Examination (UN), the dominant questions are reading because there are a lot of texts such as narrative, descriptive, recount, and procedure text, while the others skill have less portion. In fact, in this research speaking skill was the second dominant skill represented in this textbook. It means speaking has already presented appropriately.

In reality, students of Senior High School are not able to use English for communication in a proper condition. This condition could be influenced by the fact that English is considered as a foreign language instead of the second language. Meanwhile, in this research, the result showed that writing skill had the highest proportion of 35\%, followed by grammar $32 \%$, speaking $25 \%$, reading $7 \%$, and the lowest proportion was listening of just $1 \%$. It means that writing and speaking are two dominant skills than the other two skills in activities for students of this English textbook.

The Ministry of Education and Culture (2016) states that teaching language at senior high school level focuses on improving the competence of learners to be able to use English to achieve communication goals in various contexts, both oral and written. The finding of this research shows that writing skill has the highest proportion of English textbook grade XI published by kemendikbud 2014, then followed by grammar, speaking, reading and listening. This result has not suited to the goal of English learning yet since the goal focuses on improving students' communication orally and written form. It is supposed to be speaking and listening which are the dominant proportion followed by writing, reading, and grammar. The goal of the curriculum can be achieved by facilitating students on many English exposures as possible for their listening ability. In fact, this skill was the least represented in the textbook.

Chrystal (2015) states that listening is the first skill that should be acquired by the students in learning a language. Listening should acquire firstly followed by other skills naturally. Students need to be poured by many English exposures as possible in order to produce the language.

Even though listening skill is the lowest proportion in this textbook, the textbook has many activities with integrated skills. For example inactivity chapter 1 , "personal connection" the instruction of this activity was: If you get three wishes from a magical creature, what will you wish for? Write down your wishes in the space given below and share with your teacher and classmates. This activity categorized into writing and speaking based on guidance from Nation (2007) and Nation \& Macalister (2010). In connection with the above fact, in chapter 8, "The Last Leaf" is categorized into reading activity. However, teachers can combine the skills for activities in the class. They can apply this short story as a material for listening by reading the story aloud and let the students grasp the meaning first before they see the text. Then the teacher asks the student to express their idea or thought in front of the class for a speaking activity. Furthermore, activity in chapter 10, "discussion questions for Hero" (a song by Mariah Carey) the instruction of this activities were: 1 . what is the song "Hero" about? 2. According to the song "Hero", what makes a hero? 3. Who is your Hero? Why?, 4. How does this song make you feel? In this activity required the student to work on writing skill. However, before students are asked to work with the writing, the teacher should play the song and let students hear, enjoy while grasping the meaning. In this kind of activity, students' listening skill will be elaborated.

\section{CONCLUSION AND SUGGESTION}

\subsection{Conclusion}

Based on the results of this research, it can be concluded that English textbook grade XI published by Kemendikbud 2014 has the appropriate proportion on two skills (writing and speaking) however it has inappropriate proportion on two other skills (listening and reading). In fact, most of the activities in the textbook represent writing skill 
integrated with other skills. In this textbook, there are many skills that are integrated each other. Teachers' creativity and innovation are required in implementing the textbook at class.

\subsection{Suggestion}

The result of language skills' proportion in this research might help the English teachers to combine some skills for activities in the textbook. The teachers should be creative, for example: add material from other sources, internet or other books that still relate to the material in the textbook in order to help the students increase their knowledge especially for listening. Moreover, in this textbook, the proportion shows that writing skill as the highest proportion, followed by speaking, reading, and the lowest proportion was listening to skill. It is as one of evaluation for the author to evaluate the language skills proportion in each activity.

\section{REFERENCES}

Brown, H. D. (2000). Principles Of Language Learning And Teaching (4th Edition). NewYork : Addison Wesley Longman.

Kementerian Pendidikan dan Kebudayaan. (2014). Bahasa Inggris for Grade XI Senior High School. Jakarta: Kementerian Pendidikan dan Kebudayaan.

Kementerian Pendidikan dan Kebudayaan. (2016). Silabus Mata Pelajaran Sekolah Menengah Atas/Madrasah Aliyah/Sekolah Menengah Kejuruan/Madrasah Aliyah Kejuruan (Sma/Ma/Smk/Mak). Jakarta: Kementerian Pendidikan dan Kebudayaan.

Kementerian Pendidikan Nasional. (2005). Peraturan Menteri Pendidikan Nasional Republik Indonesia Nomor 11 Tahun 2005 tentang Buku Teks Pelajaran. Jakarta: Kementerian Pendidikan Nasional.

Nation, P. (1996). The Four Strands of a Language Course. TESOL in Context. 6(2), 7-12. Retrieved from http://www.victoria.ac.nz/lals/about/staff/ publications/paul-nation/1996-Four-strands.pdf

Nation, P. (2007). The Four Strands. Innovation in Language Learning and Teaching. 1(1), 1-12.

Nation, I.,\& Macalister, J. (2010). Language Curriculum Design. New York: Routledge.

Setiabudi, I. (2010). The Analysis of English Textbook "English on Sky 2" Used at the Second Year of SMP Dharma Karya, Pamulang. Skripsi, English Education Department, Faculty of Tarbiyah and Teachers' Training, UIN Syarif Hidayatullah Jakarta.

Wibisono, A. (2013). Proportion of Language Skills in English Textbook English On Sky 1. Sarjana's Thesis. University of Malang. 